\title{
The Impact of Power Quality on the Economy of Electricity Markets
}

\author{
Hector Arango, Benedito Donizeti Bonatto, \\ José Policarpo Gonçalves de Abreu and Carlos Márcio Vieira Tahan \\ Itajubá Federal University (UNIFEI) and University of São Paulo (USP)
}

Brazil

\section{Introduction}

\subsection{Basic concepts}

The main goal of this chapter is the economic valuation and prioritization of those investments which are intended to improve the power quality of the system. While most of the research work in the field of power quality was aroused by the scientific challenges to be overcome, it is fair to recognize that the practical importance of power quality hinges on the economic impact of such phenomena.

Thus, economic analysis of power quality is of the outmost significance. Such analysis, according to present day corporate doctrine, implies the assessment of the changes in the market value which are produced when an ideal scenario - where electric energy is supplied without any imperfection - is disturbed by a series of distortional events, thus leading to a loss of quality. In brief, we want to relate imperfection level with market value.

In a more practical line of thought, we wish to answer specific questions like this: how many equivalent dollars of market value are lost when the severity index of some type of imperfection increases - say - by one unit? Or - opposingly - how many dollars are won because of a decrease in severity?

Moreover, given an intervention in the markets which diminishes the index, we seek to estimate the monetary benefit of such quality improvement. As we also know the capital needed to accomplish such intervention we can introduce in the market model and the change in value added may be subsequently calculated. Then, the relation between that change and the capital invested can be compared against a hurdle rate which functions as a yardstick for the merit of the intervention. This can be used also in order to prioritize capital investments on power quality (this rather straight way of investment prioritization, becomes more complicated when the uncertainties inlaid in the quality issues are introduced).

\subsection{The quality market model outline}

Figure 1 depicts the electricity market model without considerations on quality issues. Essentially, such market is based upon the capacity of the consumers to draw value from electrical energy through an usage system (the "EE usage" rectangle on upper right). This system is fed across a supply network (the rectangle below the first one). These two systems are the physical assets from which the creation of users value $(S)$ results. The payment of users is the firm revenue (R). So the difference (U-R) can be seen as a surplus (S) obtained 
from the acquisition of energy. Subtracted from (R) are the expenses need to operate the physical assets, taxes and the remuneration of capital (financial assets), the remaining value $(\mathrm{V})$ goes to the investors, as seen at the left, (S) and (V) sum up to produce the public value $(\mathrm{W})$ added to the society. Maximization of $(\mathrm{W})$ is the ultimate goal of regulation mechanisms (Arango et al., 2008a).

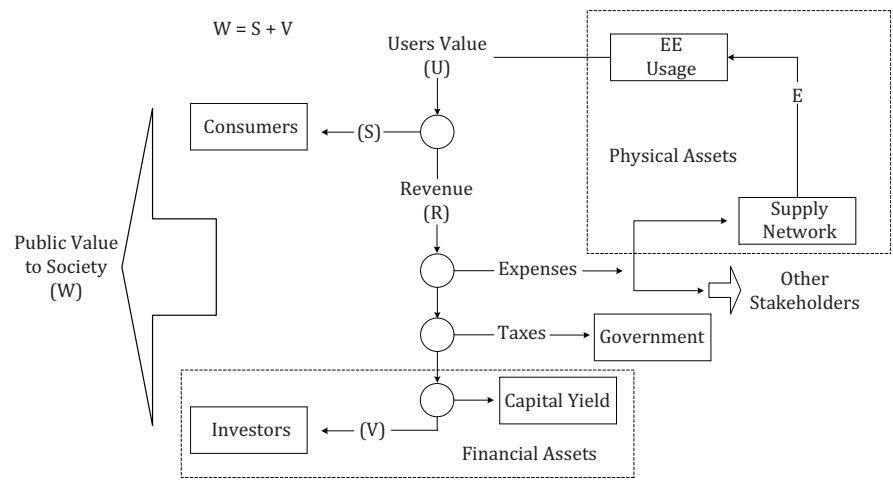

Fig. 1. Diagram of the monetary streams (someones are virtuals) taking place in an electricity market.

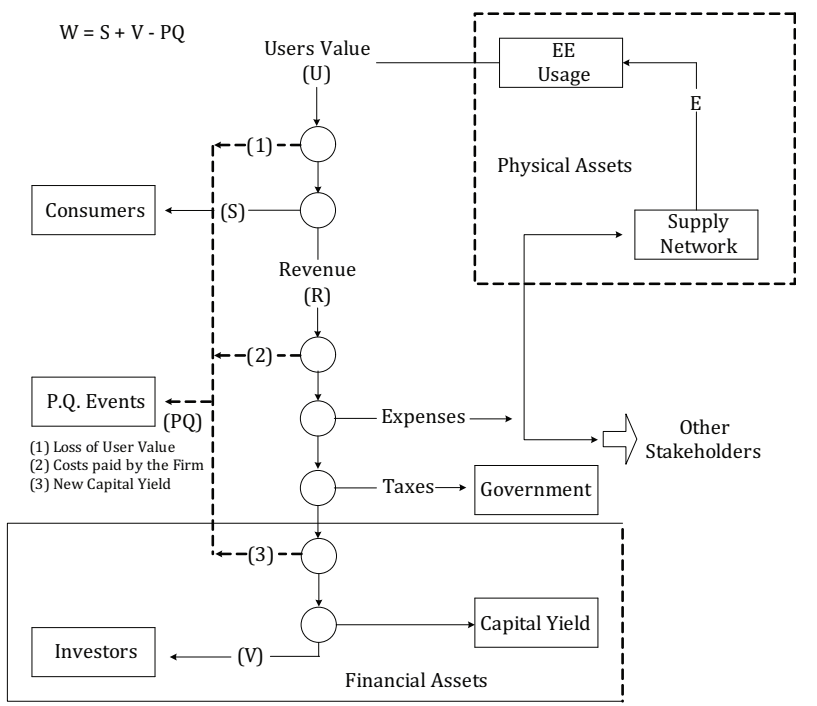

Fig. 2. Insertion of Power Quality events in the Electricity Market Model.

Figure 2 shows how the economic impact of quality events can be introduced in the previous market model. Due to the heterogeneous nature of such events they influence the customers, the firm or both. There is also an additional impact due to the capital invested in measures aimed to power quality improvement. Anyway, each of these influences can be duly taken on account and the net impact of quality on consumers' surplus and the 
companies' economic value added can be calculated. (Those influences are located in Fig. 2 as circles (1), (2) and (3)).

In this way, this new market model allows a comprehensive treatment of power quality (P.Q.) either from the point of view of the utilities, customers or society.

\section{The consumers representation}

We shall begin with a brief explanation of the consumers attitude in regard to the electrical energy (E.E.).

\subsection{Basic assumptions}

a. From any quantity (E) of Electrical Energy the consumer gets a value of use expressed in monetary terms, as a concave value-function $\mathrm{U}(\mathrm{E})$, also known as a Von NeumannMorgenstern utility curve (Von Neumann \& Morgenstern, 1944). The simplest function of such kind is a quadratic one, expressible as:

$$
\mathrm{U}(\mathrm{E})=\mathrm{a} \cdot \mathrm{E}-1 / 2 \mathrm{~b} \cdot(\mathrm{E})^{2}
$$

where (a) implies the Eagerness to use (E), while (b) portraits the Satiation due to the quantity already spent.

b. The energy is sold at a fixed Tariff $(\mathrm{T})$. Then, the purchase of a quantity (E) will demand a Payment $\mathrm{P}(\mathrm{E})$ given as:

$$
\mathrm{P}(\mathrm{E})=\mathrm{T} \cdot \mathrm{E}
$$

c. The difference between Value and Payment - whenever positive - represents a Surplus $S(E)$ which the user draws from the transaction. Based on expressions for the equalities (1) and (2) results the following expression for the Surplus.

$$
S(E)=(a-T) E-1 / 2 b \cdot(E)^{2}
$$

\subsection{The purchasing of energy}

Under the hypothesis above we postulate that the fundamental mechanism governing the purchase of E.E. can be verbalized as follows (Kreps, 1990; Jehle \& Reny, 2000):

"The consumer buys such quantities $\left(\mathrm{E}^{*}\right)$ of energy that maximize his (her) surplus."

Then, $\left(E^{*}\right)$ must satisfy the well-known first-order condition:

$$
\left.\frac{\mathrm{dS}}{\mathrm{dE}}\right|_{\mathrm{E}=\mathrm{E}^{*}}=(\mathrm{a}-\mathrm{T})-\mathrm{bE}^{*}=0
$$

Thus, for any a>T, it results the optimal quantity purchased by the customer:

$$
\mathrm{E}^{*}=(\mathrm{a}-\mathrm{T}) / \mathrm{b}
$$

This important equation relates consumption with price in the electricity market, in terms of the customer preference and the practiced tariff. The reverse equation is also very often useful:

$$
\mathrm{T}=\mathrm{a}-\mathrm{bE}
$$


From (2), (3) we shall have the optimized surplus:

$$
S^{*}=(b / 2) E^{2}
$$

and the corresponding payment:

$$
\mathrm{P}^{*}=\mathrm{aE}-\mathrm{bE}^{2}
$$

which is also the Revenue (R) of the firm.

\subsection{The diagram of economic flow of consumption}

The relationships above may be held together in a Diagram of Economic Flow as shown in Figure 3:

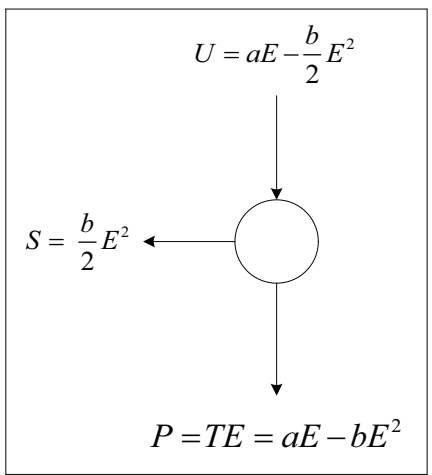

Fig. 3. Diagram of economic flow of a customer or cluster of customers.

For $\mathrm{a}=4300 \mathrm{US} \$ / \mathrm{MWh}, \mathrm{b}=500 \mathrm{US} \$ \mathrm{MWh}^{2}$ and $\mathrm{E}=8 \mathrm{TWh}$. The diagram is depicted in Figure 4:

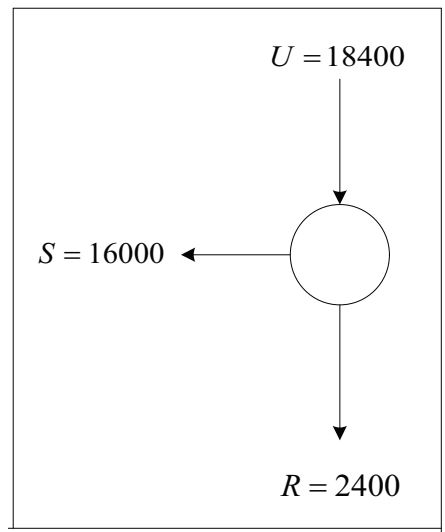

Fig. 4. Diagram of economic flow with reasonable values for the monetary streams occurring in real world.

Then, $\mathrm{T}=\mathrm{a}-\mathrm{bE}=4300-4000=300 \mathrm{US} \$ / \mathrm{MWh}$, as it should be. 


\subsection{Practical considerations}

The customers parameters $(a, b)$ are not readily known in practice. Nevertheless, they can be related to information that is far more available. First, we are familiar with the purchased annual energy (E) and the firm revenue (R), thus we are also aware of T = R/E. Second, there is a basic economic parameter describing the consumers attitude with regard to the energy which was being thoroughly studied and measured: it is the Elasticity ConsumptionPrice $(\varepsilon)$, defined as:

$$
\varepsilon=-(\mathrm{T} / \mathrm{E})(\mathrm{dE} / \mathrm{dT})
$$

Recalling the fundamental equations (4) and (5) it can be devised a formula linking $(\varepsilon)$ with (a) as:

$$
\mathrm{a}=\left(1+\varepsilon^{-1}\right) \mathrm{T}
$$

On the other hand, we always have the formula (5) which is reiterated here.

$$
\mathrm{a}-\mathrm{bE}=\mathrm{T}
$$

For example, let be $\mathrm{E}=8 \mathrm{TWh}, \mathrm{T}=300 \mathrm{US} \$ / \mathrm{MWh}, \varepsilon=0,075=7,5 \%$

Then, from (9) we shall have:

$$
\mathrm{a}=(1+1 / 0,075) 300=4300 \text { US\$ } / \text { MWh }
$$

and using (5) it results:

$$
\mathrm{b}=(\mathrm{a}-\mathrm{T}) / \mathrm{E}=(4300-300) / 8=500 \mathrm{US} \$ / \mathrm{MWh}^{2}
$$

Note that:

$$
\mathrm{R}=(4300 \times 8)-(500 \times 82)=2400 \mathrm{MUS} \$=8 \mathrm{TWh} \times 300 \mathrm{US} \$ / \mathrm{MWh}
$$

as it should be.

\section{Observation:}

$\varepsilon$ varies with the point of operation of the customer. The value used in the calculus must be the elasticity computed for the same $(\mathrm{T})$ obtained above. When $\varepsilon$ was obtained for a different tariff $\mathrm{T}^{\prime}$, i.e.,

$$
\varepsilon^{\prime}=-\left(T^{\prime} / E\right)(d E / d t)=T^{\prime} / b E=T^{\prime} /\left(a-T^{\prime}\right)
$$

We must retrieve $\varepsilon$ as:

$$
\mathrm{a}=\left(1+\varepsilon^{-1}\right) \mathrm{T}=\left(1+\left(\varepsilon^{\prime}\right)^{-1}\right) \mathrm{T}^{\prime}
$$

Then:

$$
\left(1+\varepsilon^{-1}\right)=\left(1+\left(1+\left(\varepsilon^{\prime}\right)^{-1}\right) \mathrm{T} / \mathrm{T}\right.
$$

which results in:

$$
\varepsilon^{\prime}=1 /\left(\left(1-\varepsilon^{-1}\right)\left(\mathrm{T} / \mathrm{T}^{\prime}\right)-1\right)
$$

Then

$$
\varepsilon=1 /\left(1+\left(\varepsilon^{\prime}\right)^{-1}\right)\left(\mathrm{T}^{\prime} / \mathrm{T}\right)-1
$$


For example, let be $\mathrm{T}^{\prime}=150$ US $\$ / \mathrm{MWh}$. Then, we shall have:

$$
\varepsilon^{\prime}=1 / 27,66666667
$$

or:

$$
\varepsilon^{\prime}=0,036144578
$$

giving, as expected,

$$
\varepsilon=1 /\left(28,66666667 \times(150 / 300)^{-1}\right)=0,075
$$

For example, suppose the elasticity is known to be $\varepsilon^{\prime}=0,036144578$ for $\mathrm{T}^{\prime}=150 \mathrm{US} \$ / \mathrm{MWh}$. Then, we shall have $\varepsilon=0,075$ for $\mathrm{T}=300 \mathrm{US} \$ / \mathrm{MWh}$.

\section{The firm representation}

\subsection{A few words on capital and rates of return}

We start with a brief description of capital. Total capital (B) is composed by equity (A) contributed by the Shareholders - and Debt (D) - due to the Bondholders.

It is customary to define a Leverage Factor $(\delta)$ such that $(D=\delta B)$ to express the level in which the firm is indebted. Moreover:

1. An interest must be paid over debt at a convened debt-rate $\left(\mathrm{r}_{\mathrm{D}}\right)$.

2. A remuneration should remain available over equity at an expected rate of return $\left(\mathrm{r}_{\mathrm{A}}\right)$.

3. Interest is not subjected to taxation. Remuneration, instead, is fully taxable on a tax rate $(t)$.

4. $r_{D}$ and $r_{A}$ combine to produce the weighted-average cost of capital (WACC) where:

$$
\mathrm{WACC}=\mathrm{r}_{\mathrm{w}}=(1-\delta) \mathrm{r}_{\mathrm{A}}+\delta(1-\mathrm{t}) \mathrm{r}_{\mathrm{D}}
$$

where $t$ is the tax rate.

\subsection{Financial statements}

We shall represent the firms by a statement of their performance over a given period or financial exercise.

A statement begins always with the total Revenue (R), from which is deducted the Cost, thus leading to the so called Result.

In order to make clear our choice of Statement, two types of such instruments are to be considered:

1. Accounting statement

Is the traditionally used and published (according to rules of USGAAP - United States

Generally Accepted Accounting Practices), which Cost includes expenses and interest on debt (D). Its Result is called Net Profit (L).

2. Economic value statement

Cost includes not only expenses and interest, but the yield on the total capital (B). Its Result is called Economic Value Added (V) (Martin \& Petty, 2000).

In the following, we shall use the Economic Value Statement type, recognizing that it represents better the modern principles of corporate finance. Nevertheless, in order to highlight the distinctive features, some examples will be worked on both statements. 


\subsection{Modeling the firm}

The supplier is moulded as a system (Jensen \& Meckling, 1976) whose input is the revenue (R). The various components of the economic cost (C) are then subtracted. As (C) includes de yield of all the capital (debt and equity) the remaining quantity (output or result) stands for the value (V) created above the expectations of investors. The firm surplus (V) is known as Economic Value Added or Economic Profit.

One of the distinctive features of our representation is the proposal of a cost structure, that is to say, an explicit dependence among the various costs with the basic variables: supplied energy (E) and capital investment (B).

The proposed structure, i.e. the supplier model, is presented as a diagram of economic flow in Figure 5.

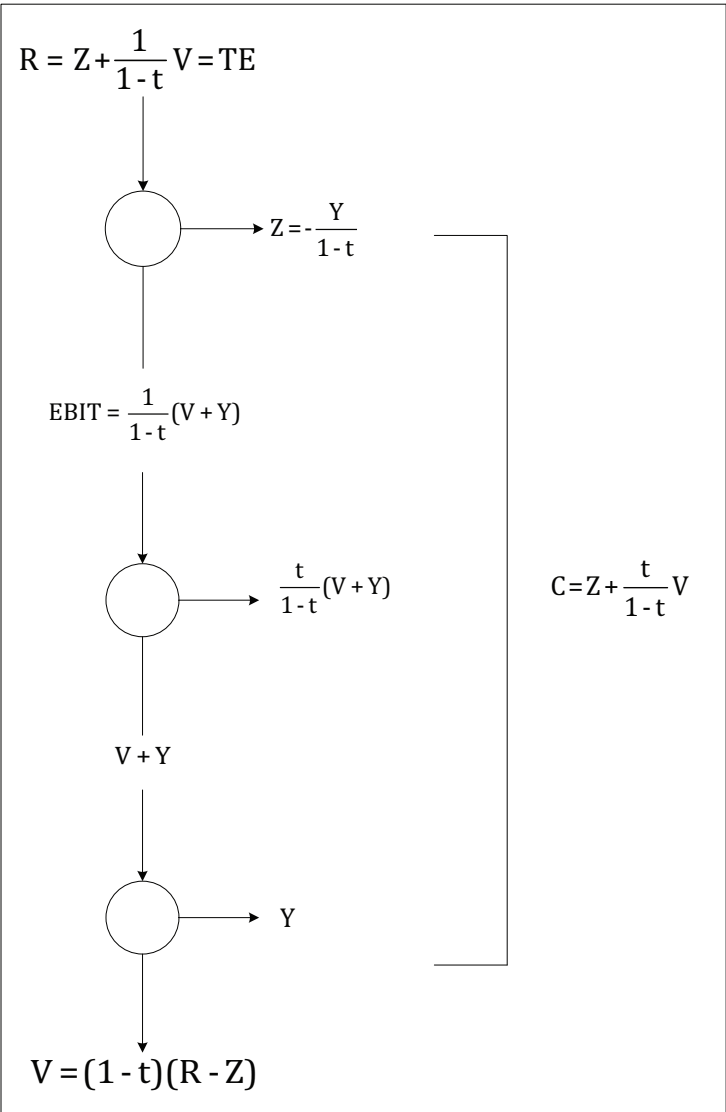

Fig. 5. Diagram of the Economic Value Statement of a distribution company (DISCO).

where the symbols mean:

$\mathrm{R}=$ Receipt; $\mathrm{T}=$ Tariff; $\mathrm{C}=$ Economic Cost; $\mathrm{Z}=$ Total Cost at Equilibrium; $\mathrm{dB}=$ Depreciation of Physical Assets; $Y=r_{w} B=$ Yield of Capital (equity plus debt); $V=$ Economic Value Added or economic profit; EBIT $=$ Earnings before interest and taxes 
Note that the cost functions $C(E, B)$ are depending also from certain parameters (e, p, d, w) portraying the operational and corporative efficiency of the firm on one hand and its technological standards on the other.

Note that, a distinctive feature, our market model brings a cost structure, that is to say, a functional dependence among each component of cost and the fundamental variables, which are quantities of supply and capital investment. In our case the variables are the energy purchased (E) and the investments in scale (B) and quality (Q).

As cost components we have the functions:

eE - Operational expenses, energy bought from generation companies and other charges.

$\mathrm{p}\left(\mathrm{E}^{2} / \mathrm{B}\right)$ - Cost of energy lost in the electric network.

$\mathrm{dB}$ - Depreciation of physical assets.

$r_{w} B$ - Reward to investors

\subsection{The firm with optimal allotment of capital}

The investment $B$ has an optimal value $B^{*}$ for which $Z$ attains its minimal value $Z^{*}$. $B^{*}$ is obtained by zeroing the derivative of $Z(E, B)$ with respect to $B$ :

$$
\frac{\partial Z}{\partial B}=-\frac{p E^{2}}{B^{2}}+k=0
$$

Then

$$
\mathrm{B}^{*}=\left(\frac{\mathrm{p}}{\mathrm{k}}\right)^{\frac{1}{2}} \mathrm{E}
$$

and

$$
\mathrm{Z}^{*}=\left(\mathrm{e}+2(\mathrm{pk})^{\frac{1}{2}}\right) \mathrm{E}=\mathrm{cE}
$$

Note that the average price remains constant.

\subsection{The firm in economic equilibrium}

Another condition of interest implies $\mathrm{V}=0$. Then we shall have:

$$
\mathrm{R}=\mathrm{C}=\mathrm{Z}
$$

In this case, the supplier firm is said to be in Economic Equilibrium.

When the firm is simultaneously with optimal investment and an economic equilibrium we shall have:

$$
\mathrm{R}=\mathrm{C}=\mathrm{Z}=\mathrm{cE}
$$

where

$$
\mathrm{c}=\mathrm{e}+2(\mathrm{pk})^{1 / 2}
$$

As will be explained later, a regulated firm should belong to this particular class. 


\section{Peculiarities of electricity markets}

\subsection{The company as a natural monopoly}

It is important to note that the distribution company (DISCO) owns the electric network which allows the physical delivery of E.E. to the customers. Any other firm wishing to compete in the business should construct another network replicating the geographical layout of the original one. It is obvious that the entry of such competitor will decrease the overall market efficiency (Kupfer \& Hasenclever, 2002).

In such conditions, the disco has the market power required to impose whatever tariff which it has in mind. Clearly, the disco goal is to maximize its economic value added (V). Thus, it can be easily concluded that such tariff ought to satisfy:

$$
\frac{\mathrm{dR}}{\mathrm{dE}}=\frac{\mathrm{dZ}}{\mathrm{dE}}
$$

Assuming that the company optimizes its investments, the equality (19) will lead to:

$$
\mathrm{a}-\mathrm{ZbE}=\mathrm{c}
$$

Then,

$$
\mathrm{E}_{\mathrm{M}}=(\mathrm{a}-\mathrm{c}) / 2 \mathrm{~b}
$$

and the "monopolistic" tariff will be:

$$
\mathrm{T}_{\mathrm{M}}=(\mathrm{a}+\mathrm{c}) / 2
$$

Substituting (21) in the formula of (V), given in Figure 3, we shall have:

$$
V_{M}=(1-t)(R-Z)_{M}=(1-t)\left((a-c)-b E_{M}\right) E_{M}=(1-t)\left((a-c)^{2} / 4 b\right)
$$

\subsection{The regulated firm}

It is widely accepted that monopolistic tariffs impose on the customers an unfair weight. Being the electricity supply a public service, it should be regulated in order to attain maximum generation of social welfare (Beesleyand \& Littlechild, 1989).

As social welfare is a debatable and elusive notion, regulators usually adopt, as a reasonable proxy, the quantity (Friedman, 2002):

$$
\mathrm{W}=\mathrm{S}+\mathrm{V}
$$

i.e., the sum of the consumers' surplus and the value created by the utility, (which was called Market Output). Nevertheless, the unconstrained maximization of $\mathrm{W}$ leads to nonsensical results implying the firm's collapse. The constrained solution requires that the firm be operated in economic equilibrium. Then, for optimum investment, the regulated company is compelled to operate satisfying:

$$
\mathrm{aE}-\mathrm{bE}^{2}=\mathrm{cE}
$$

Thus, leading to:

$$
E_{R}=(a-c) / b
$$


and then

$$
\mathrm{T}_{\mathrm{R}}=\mathrm{C}
$$

\subsection{Example of a regulated operation of a firm}

In order to enlighten the discussion on monopolist and regulated firms, Figure 6 shows the same distribution company supplying the same customers when operating free (i.e., using $\left.\mathrm{T}_{\mathrm{M}}\right)$ and when regulated $\left(\mathrm{T}_{\mathrm{R}}\right)$.

MONOPOLISTIC

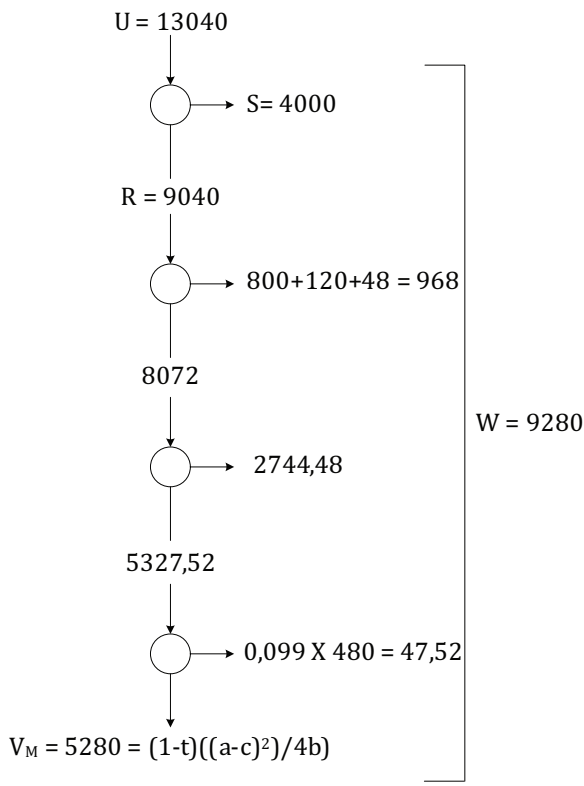

Optimized $\mathrm{B}_{\mathrm{M}}{ }^{*}=480 \mathrm{M}$ US\$
REGULATED

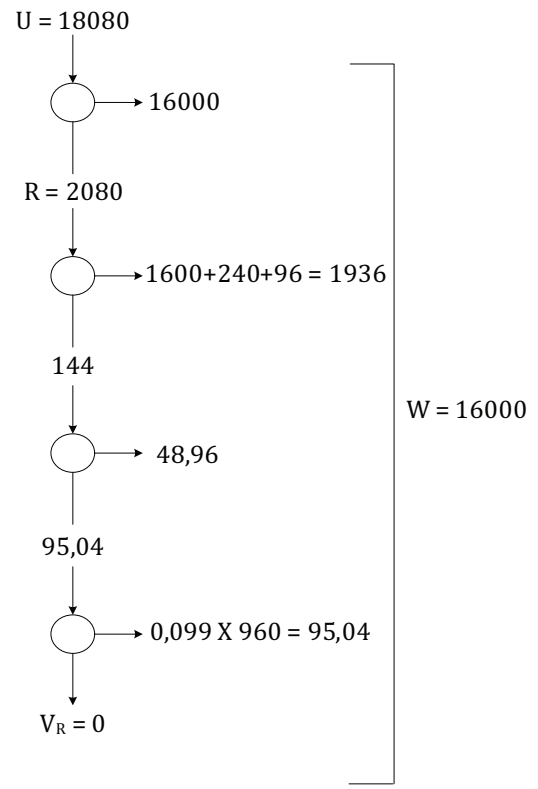

Optimized $\mathrm{B}_{\mathrm{R}}{ }^{*}=960 \mathrm{M}$ US\$

(a) Monopolistic

(b) Regulated

Fig. 6. Monopolistic and regulated diagram of economic flow of a given firm.

Let be an utility and its costumers for the following parameters.

Firm:

$\mathrm{e}=200 \mathrm{US} \$ / \mathrm{MWh}$

$\mathrm{p}=3600 \mathrm{US}^{2} / \mathrm{MWh}^{2}$

$\mathrm{d}=0,10$

$\mathrm{r}_{\mathrm{w}}=0,099$

$\mathrm{c}=260 \mathrm{US} \$ / \mathrm{MWh}$

Customers:

$\mathrm{a}=4260 \mathrm{US} \$ / \mathrm{MWh}$ 
$\mathrm{b}=500 \mathrm{US} \$ / \mathrm{MWh}^{2}$

Note: the parameters already given correspond to a stylized albeit of a real medium-size utility supplying a cluster of customers, typical of a developing country.

In such case we shall have:

Monopolistic

$\mathrm{T}_{\mathrm{M}}=2260 \mathrm{US} \$ / \mathrm{MWh}$

$\mathrm{E}_{\mathrm{M}}=4 \mathrm{TWh}$

Regulated

$\mathrm{T}_{\mathrm{R}}=260 \mathrm{US} \$ / \mathrm{MWh}$

$\mathrm{E}_{\mathrm{R}}=8 \mathrm{TWh}$

leading to the diagram of economic flow of Figure 6:

\subsection{The hurdle rate}

We shall assume that every distribution utility seeks to maximize its performance, expressed as the Result of its exercise Statement. But a question arises: what type of statement is to be adopted?

As was said, there are two basic types, whose results are net profit and economic value added, respectively.

On the other hand, consider a project applicable to the company. We want to know if this project is convenient.

We shall define the hurdle rate (h) as the one for which the project does not change the Result produced by the company.

The hurdle rate can be obtained for both types of statement according to the incremental analysis on Figure 7.

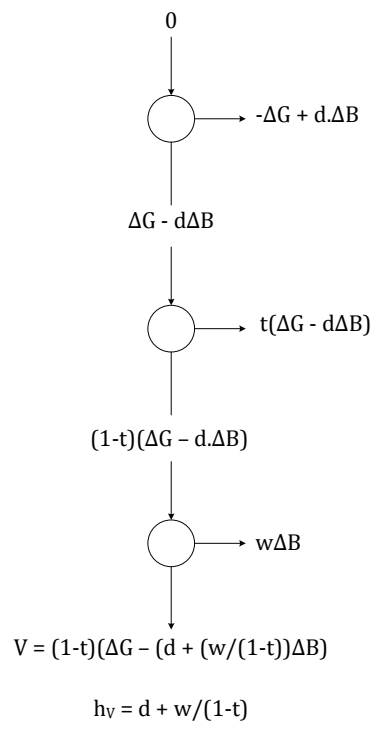

(a)

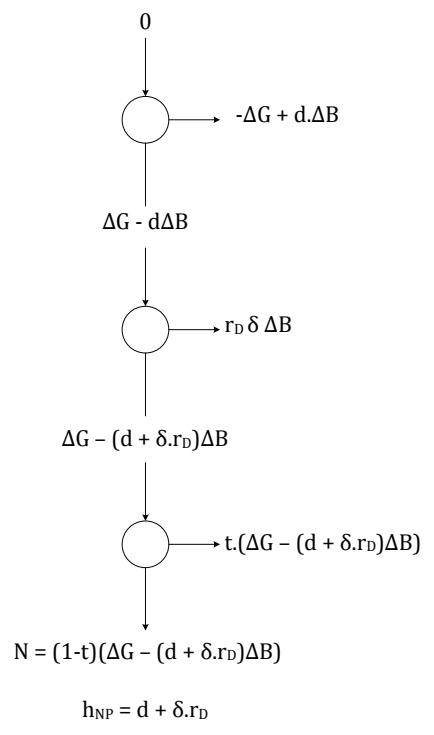

(b)

Fig. 7. Hurdle rate for economic value added and net-profit statements. 
We can see that the hurdle rate depends heavily on the type of statement, that is to say, on the Result to be maximized. Substituting $r_{w}$ in Figure 7 (a) for its value in (13) we shall have:

$$
\mathrm{h}_{\mathrm{V}}=\mathrm{d}+\frac{1-\delta}{1-\mathrm{t}} \mathrm{r}_{\mathrm{A}}+\delta \mathrm{r}_{\mathrm{D}}=\mathrm{h}_{\mathrm{NP}}+\frac{(1-\delta) \mathrm{r}_{\mathrm{A}}}{1-\mathrm{t}}
$$

That is to say, the hurdle rate required to comply with economic value added is greater than the one for net profit by excess equal to:

$$
\frac{1-\delta}{1-t} r_{A}
$$

Example:

Let be: $d=0,05, r_{A}=0,1595, r_{D}=0,075$ and $\delta=0,55$. Then, $r_{w}=0,099$ and:

$$
\begin{aligned}
& \mathrm{h}_{\mathrm{V}}=0,05+\frac{0,099}{0,66}=0,20 \quad \mathrm{~h}_{\mathrm{NP}}=0,05+0,55 \times 0,075=0,09125 \\
& \mathrm{~h}_{\mathrm{V}}=\mathrm{h}_{\mathrm{NP}}+0,10875=\frac{1-\delta}{1-\mathrm{t}} \gamma_{\mathrm{A}}=0,10875
\end{aligned}
$$

For the sake of comparison, Figure 8 depicts the accounting statements for the monopolistic and regulated operation of the same firm under the hypothesis of leverage factor $\delta=0,55$, $r_{A}=0,1595$ and $r_{D}=0,75$.

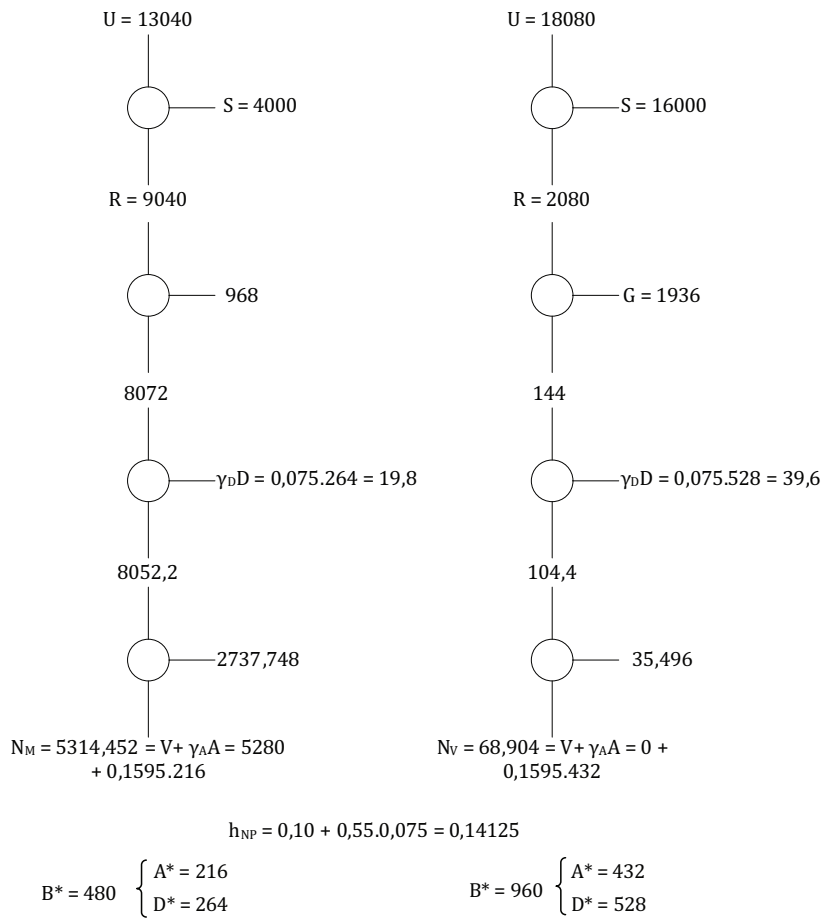

Fig. 8. Net profit statements for the data. 
Note that $\mathrm{L}-\mathrm{V}$ is always equal to the equity yield $\mathrm{r}_{\mathrm{A}}$. A as appears at the bottom of both diagrams of economic flows.

\subsection{The electricity Market Model (M.M.)}

The (M.M.) is obtained by simply joining the two representations already made, as shown in simplified form in Figure 9.

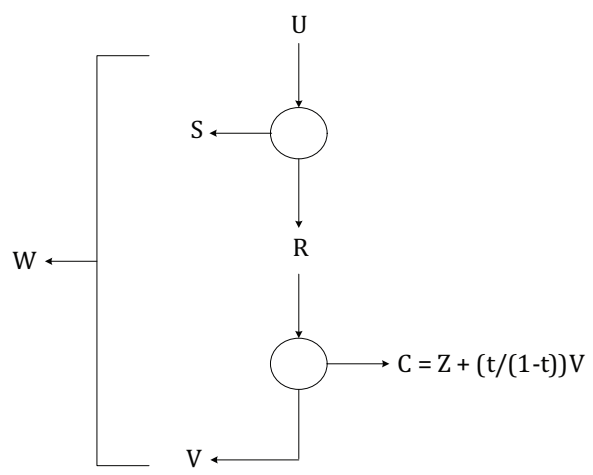

Fig. 9. The basic Electricity Market Model.

Now the total diagram can be interpreted as a single system whose input is the value of use of the electric energy and whose output is the sum of the consumers' surplus and the company economic value added.

\section{The Insertion of quality in the electricity Market Model}

\subsection{Basic considerations}

The approach to power quality is built on the notion of quality event, that is to say, any occurrence leading to some imperfection of the product (electric energy) or service (electric supply). Quality events are of the most different nature and consequences. In order to assess their effects, (especially for regulatory purposes) each type of event is associated to some numeric index of severity.

As an example, take the important class of events which cause interruptions on the electrical supply. This type of imperfections is customarily described by the average (or expected) time during which customers are de-energized (DTD) and the average frequency of interruption (DFD). These are technical indexes which affect both consumers and suppliers.

The functional dependence between such indexes and their economic impacts may be highly complex and heterogeneous. Thus, in order to get a unified and simple picture we shall assume that quality can be introduced as an additional cost $\left(\mathrm{C}_{\mathrm{Q}}\right)$ (Arango et al., 2008b, Arango et al., 2010), which must be paid by consumers and producers in various proportions.

\subsection{The quality cost}

We shall call $\left(\mathrm{C}_{\mathrm{Q}}\right)$ quality cost. The structure of $\left(\mathrm{C}_{\mathrm{Q}}\right)$ will be assumed as:

$$
\mathrm{C}_{\mathrm{Q}}=\mathrm{qE}^{2} / \mathrm{Q}
$$


In this formula $Q$ represents the capital investment which is devoted mainly to enhance power quality. Please note that $Q$ adds to the capital (B) already considered, which is chiefly invested on the network size. In this line, Q and B shall be usually referred as "quality" and "scale" investment, respectively.

Of course, more realistic assumptions for the economical impact of quality may be done, but the approach above allows obtaining analytic answers leading to a better and faster understanding of such impact. Otherwise, such analysis gives satisfactory results in a broad class of practical problems regarding power quality.

The electricity market model including quality issues is depicted in Figure 10.

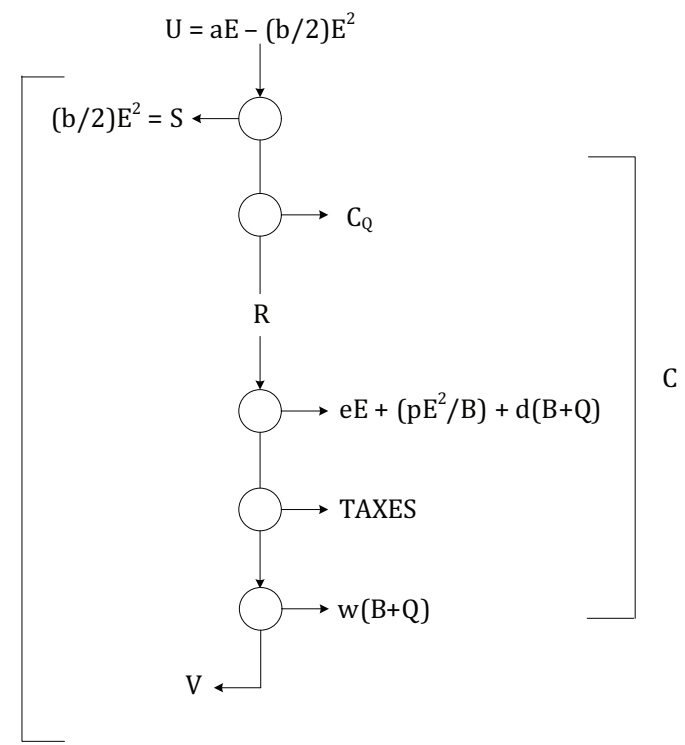

Fig. 10. The electricity market model considering Power Quality.

\subsection{The purchasing of polluted energy}

The consumption of imperfect energy is governed by the same principle of surplus maximization introduced in section for perfect energy. In the present case we shall have:

$$
S=U-R-C_{Q}=(a-T) E-(b / 2+q / Q) E^{2}
$$

Then

$$
\left.\frac{d S}{d E}\right|_{E=E^{*}}=a-T-\left(b+\frac{2 q}{Q}\right) E=0
$$

Thus

$$
E^{*}=\frac{a-T}{b+\frac{2 q}{Q}}
$$


and

$$
S^{*}=1 / 2(b+2 q / Q) E^{2}
$$

\subsection{Optimizing the investment on quality}

Note that investment on quality $Q$ can be optimized in the same way that the investment on network scale $B$. Then, we shall have:

$$
\mathrm{Q}^{*}=\left(\frac{\mathrm{q}}{k}\right)^{\frac{1}{2}} E
$$

and

$$
C_{Q}^{*}=(q k)^{\frac{1}{2}} E
$$

leading to an optimized cost

$$
\tilde{\mathrm{c}}=\mathrm{e}+(p k)^{\frac{1}{2}}+(q k)^{\frac{1}{2}}=c+(q k)^{\frac{1}{2}}
$$

where c comes from (18).

\subsection{The regulation of Power Quality}

Power quality regulation adjusts to the following rationale:

The basic regulated variable is price (i.e., the electricity tariff). Moreover, recall that the main goal of regulation is the maximization of social welfare which is attained when the supplier company operates at equilibrium, that is to say, with zero economic profit. Additionally, the agency requires that the company have "efficient costs and prudent investments". Such criteria are met trough a benchmark procedure, searching for the parameters that should be adequate for a virtual or reference company adapted to the real conditions of supply (such as area to be served, number of customers, network technology, etc.) while investment of capital in quality must be optimal in the sense discussed in 4.3.

In such conditions, the agency obtains the average tariff by dividing the economic cost by the energy to be sold.

The crucial point of this process is the calculus of the quality cost. Observe that the parameter $q$ comes from the reference company and $Q^{*}$ is the optimized capital. We assume that the corresponding quality $\operatorname{cost} \mathrm{C}_{\mathrm{Q}}$ is univocally related to the severity index. The index value which corresponds to the $\left(\mathrm{C}_{\mathrm{Q}}{ }^{*}\right)$ of the reference company is obtained as the practical target to be pursued by the regulated firm. In other words, the agency includes in the total cost allowed to the company the $\mathrm{C}_{\mathrm{Q}}{ }^{*}$ associated with the target index, expecting that the customers receive exactly such level of quality.

If a particular customer is committed to a lesser quality level, the agency will require that the firm pay to him (her) a monetary compensation (usually as a discount in the next electricity bill) equal to the difference between the actual and the target cost of quality. This implies an effective tariff for which the consumer pays only for the quality level that he or she is actually receiving. The process described above is presented in Figure 11. 
The company parameters in the case outlined are:

$\mathrm{e}=200 \mathrm{US} \$ / \mathrm{MWh} \mathrm{p}=3600 \mathrm{US}^{2} / \mathrm{MWh}^{2} \mathrm{q}=1600 \mathrm{US}^{2} / \mathrm{MWh}^{2} \mathrm{~d}=0,10 \mathrm{w}=0,099$

Assuming $\mathrm{E}=8 \mathrm{TWh}$ the customer parameters come to be:

$\mathrm{a}=4320$ US $\$ / \mathrm{MWh} \mathrm{b}=500 \mathrm{US} \$ / \mathrm{MWh}^{2}$

and the optimal investments result in

$\mathrm{B}^{*}=960$ MUS $\$ \mathrm{Q}^{*}=640$ MUS\$

This leads to the flow diagram of Figure 11. In this example the investment in quality is one half of the optimum level.

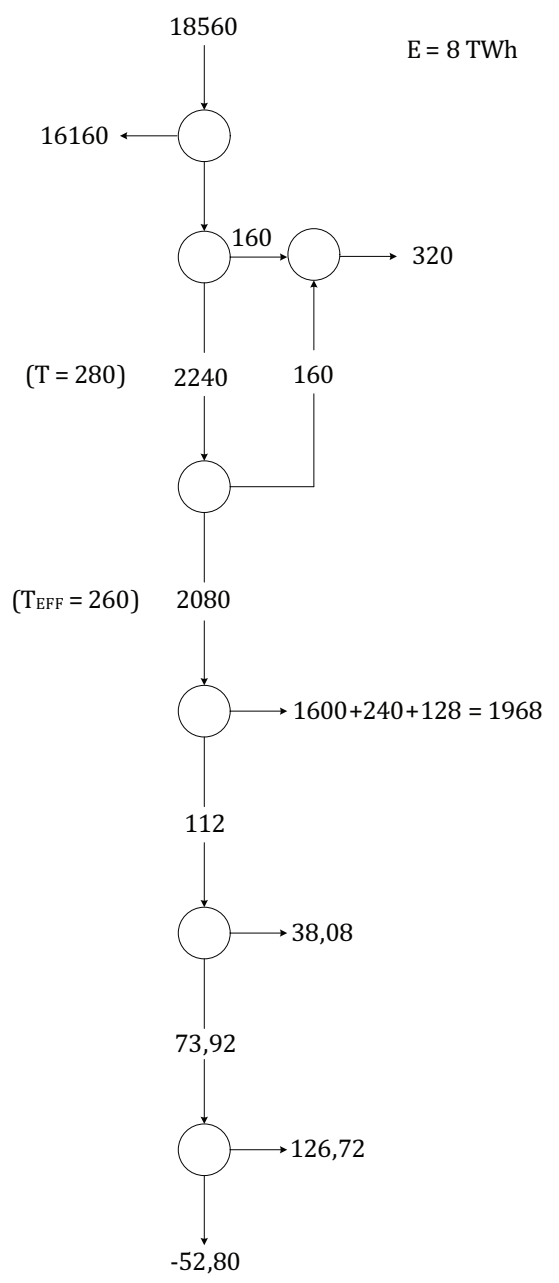

Fig. 11. Diagram of economic flows of the company when under-invested, with compensation.

Then, the cost $C_{Q}$ is two times of the optimized cost $C_{Q}{ }^{*}=$ MUS $\$ 160$. 
But the company is required to return to the customer the difference MUS\$320 - MUS\$160 = MUS\$160 as a consequence, the consumer pays as effective tariff equal to 260 US\$/MWh, which corresponds to the degradated energy which he (she) receives.

Note that the company in such conditions has a negative V. Thus, compensation also acts as a disincentive for underinvestment and a stimulus for optimal use of capital.

\section{Conclusions}

Along the chapter we have laid the foundations of an Electricity Market Model, named TAROT - Tariff Optimization, which:

a. allows for the consumers representation, featuring the surplus that they draw for the purchasing of energy;

b. considers the basic goal of the regulatory frame, namely the maximization of the social value generated by the market transactions;

c. favors the insertion of the quality levels of supply expressed as quality costs and quality improvements as capital investment;

d. unifies the regulatory frame - initially restricted to a cap-price of the energy disregarding its imperfections - optimizing both the scale and the quality portions of total invested capital.

Other applications can be devised on the same lines of thought. Perhaps the main advantage of this approach lies in this integrative potential which allows treating problems of very diverse nature and characteristics under a unified insight.

\section{References}

Arango, H.; Abreu, J. P. G.; Bonatto, B. D.; Tahan, C. M. V.; Kagan, N. \& Gouvea, M. R. (2008). A Model for Electricity Markets: The impact of Regulation on Value, Proceedings of the International Conference on the European Electricity Market (EEM 2008), Lisbon - Portugal, May 28-30, 2008.

Arango, H.; Abreu, J. P. G.; Bonatto, B. D.; Tahan, C. M. V.; Kagan, N. \& Gouvea, M. R. (2008). Modelling the Influence of Power Quality on the Creation of Market Value, Proceedings of the 13th International Conference on the Quality of Power (ICHQP 2008), Wollongong, New South Wales, Australia, Sept. 28 -Oct. 1st, 2008, IEEE/PES, USA.

Arango, H.; Abreu, J. P. G.; Bonatto, B. D.; Tahan, C. M. V.; Kagan, N. \& Gouvea, M. R. (2008). The Influence of Quality on the Creation of Economic Value in Electricity Markets, Proceedings of the 14th International Conference on the Quality of Power (ICHQP 2010), Bergamo, Italy, Sept. 26-29, 2010, IEEE/PES, USA.

Beesleyand, M. E. \& Littlechild, S. C. (1989). The Regulation of Privatized Monopolies in the U.K.. RAND Journal of Economics, Vol. 20, No.2, Autumn 1989, pp. 454-472.

Friedman,L. (2002). The Microeconomics of Public Policy Analysis, Princeton University Press.

Jehle, G. A. \& Reny, J. P. (2000). Advanced Microeconomic Theory, 2nd ed., Addison Wesley Longman.

Jensen, M. C. \& Meckling, W. H. (1976). Theory of the firm: Managerial Behaviour, Agency Costs and Ownership Structure, Journal of Financial Economics, Vol. 3, 1976, pp. 305360.

Kreps, D. (1990). A Course in Microeconomic Theory, Ed. Harvester \& Wheatshaf.

Kupfer, D. \& Hasenclever, L. (2002). Economia Industrial, Ed. Campus-Elsevier. 
Martin, J. D. \& Petty, J. W. (2000). Value Based Management, Harvard Business School Press, Boston, 2000.

Von Neumann, J. \& Morgenstern, O. (1944). Theory of Games and Economic Behavior, V. Press, Princeton, USA. 


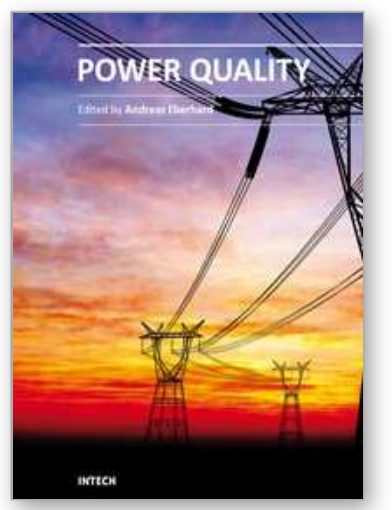

\author{
Power Quality \\ Edited by Mr Andreas Eberhard
}

ISBN 978-953-307-180-0

Hard cover, 362 pages

Publisher InTech

Published online 11, April, 2011

Published in print edition April, 2011

Almost all experts are in agreement - although we will see an improvement in metering and control of the power flow, Power Quality will suffer. This book will give an overview of how power quality might impact our lives today and tomorrow, introduce new ways to monitor power quality and inform us about interesting possibilities to mitigate power quality problems.

\title{
How to reference
}

In order to correctly reference this scholarly work, feel free to copy and paste the following:

Hector Arango, Benedito Donizeti Bonatto, José Policarpo Gonçalves de Abreu and Carlos Márcio Vieira Tahan (2011). The Impact of Power Quality on the Economy of Electricity Markets, Power Quality, Mr Andreas Eberhard (Ed.), ISBN: 978-953-307-180-0, InTech, Available from: http://www.intechopen.com/books/powerquality/the-impact-of-power-quality-on-the-economy-of-electricity-markets

\section{INTECH}

open science | open minds

\author{
InTech Europe \\ University Campus STeP Ri \\ Slavka Krautzeka 83/A \\ 51000 Rijeka, Croatia \\ Phone: +385 (51) 770447 \\ Fax: +385 (51) 686166 \\ www.intechopen.com
}

\author{
InTech China \\ Unit 405, Office Block, Hotel Equatorial Shanghai \\ No.65, Yan An Road (West), Shanghai, 200040, China \\ 中国上海市延安西路65号上海国际贵都大饭店办公楼 405 单元 \\ Phone: +86-21-62489820 \\ Fax: +86-21-62489821
}


(C) 2011 The Author(s). Licensee IntechOpen. This chapter is distributed under the terms of the Creative Commons Attribution-NonCommercialShareAlike-3.0 License, which permits use, distribution and reproduction for non-commercial purposes, provided the original is properly cited and derivative works building on this content are distributed under the same license. 